\title{
Peran Pengawas dalam Meningkatkan Efektivitas Penggunaan dan Pengembangan Media Pembelajaran Pendidikan Agama Islam (PAI)
}

\author{
Musbahaeri $^{1}$ * \\ ${ }^{1}$ Kementerian Agama, Kabupaten Bulukumba, Sulawesi Selatan, Indonesia. \\ * Korespondensi Penulis. E-mail: musbahaeri@gmail.com
}

\begin{abstract}
Abstrak
Kualitas pembelajaran Pendidikan Agama Islam (PAI) perlu terus ditingkatkan karena PAI adalah mata pelajaran yang berorientasi pada pembentukan akhlak peserta didik khususnya sikap spiritual dan sosial. Salah satu hal yang berpengaruh dalam meningkatkannya adalah media pembelajaran. Guru PAI dituntut untuk menggunakan dan mengembangkan media pembelajaran untuk membantunya dalam pelaksanaan pembelajaran. Media amat penting dalam mengantar dan memudahkan peserta didik untuk memahami materi-materi PAI yang kompleks, apalagi materi pembelajaran yang terkait dengan hal-hal transenden. Pengawas PAI harus pula berperan aktif dalam efektivitas penggunaan dan pengembangan media pembelajaran PAI. Peran pengawas bisa diwujudkan dengan mengoptimalkan supervisi akademik, menjadi motivator untuk menggerakkan guru PAI dalam mengembangkan media, menjadi peneliti untuk melakukan pengembangan-pengembangan media, menjadi penilai untuk mengevaluasi pelaksanaan pembelajaran, menjadi konsultan untuk membantu menagtasi masalah yang dihadapi guru, menjadi sumber inspirasi agar guru terinspirasi dari peran serta pengawas, dan menjadi pelopor perubahan untuk melakukan kreasi dan inovasi pembelajaran.
\end{abstract}

Kata Kunci: Media Pembelajaran PAI, Guru PAI, Pengawas PAI

\section{Role of Supervisors in Increasing the Effectiveness of the Use and Development of Islamic Education Learning Media (PAI)}

\begin{abstract}
The quality of learning Islamic Education (PAI) needs to be improved because PAI is a subject oriented to the moral formation of students, especially spiritual and social attitudes. One of the things that has an effect on improving it is learning media. PAI teachers are required to use and develop learning media to assist them in implementing learning. The media is very important in delivering and facilitating students to understand complex PAI materials, especially learning materials related to transcendent things. PAI supervisors must also play an active role in the effectiveness of the use and development of PAI learning media. The role of supervisors can be realized by optimizing academic supervision, becoming a motivator to move PAI teachers in developing media, becoming researchers to carry out media developments, becoming an evaluator to evaluate the implementation of learning, becoming a consultant to help address problems faced by teachers, becoming a source of inspiration for teachers inspired by supervisory roles, and became a pioneer of change to make learning creations and innovations.
\end{abstract}

Keywords: PAI Learning Media, PAI Teachers, PAI Supervisors 


\section{PENDAHULUAN}

Pendidikan Agama Islam (PAI) adalah usaha sadar atau kegiatan yang disengaja dilakukan untuk membimbing sekaligus mengarahkan anak didik menuju terbentuknya pribadi yang utama (insan kamil) berdasarkan nilai-nilai etika islam dengan tetap memelihara hubungan baik terhadap Allah Swt (HablumminAllah) sesama manusia (hablumminannas), dirinya sendiri dan alam sekitarnya. ${ }^{1}$ Artinya, orientasi utama PAI adalah pembentukan peserta didik yang memiliki karakter religius dan sosial.

Pendidikan Agama Islam (PAI) sudah menjadi bagian terpenting dalam kurikulum pendidikan Nasional dan sudah dilaksanakan mulai dari jenjang pendidikan dasar hingga jenjang pendidikan tinggi. ${ }^{2}$ Apalagi pada kurikulum 2013 PAI mendapatkan tambahan jam pelajaran dalam struktur kurikulum. Hal itu menunjukkan bahwa pemerintah memiliki perhatian besar terhadap pembelajaran PAI demi untuk pembentukan karakter peserta didik. Hasilnya akan kita nikmati nanti, walaupun saat ini disadari bahwa hasil pembelajaran PAI ternyata belum sesuai dengan tujuan pendidikan agama Islam itu sendiri atau masih jauh dari harapan. Artinya, belum semua peserta didik menunjukkan dan memiliki karakter baik atau akhlak yang mulia secara utuh. Dapat dikatakan bahwa pembelajaran PAI di sekolah belum efektif dalam membangun karakter bangsa atau dalam membina akhlak siswa-siswanya.

Guru PAI memang memegang peran yang sangat penting dan strategis sebab dia bertanggung jawab mengarahkan anak didiknya dalam hal penguasaan ilmu agama Islam dan penerapannya dalam kehidupan dan dalam menanamkan dan memberikan tauladan yang baik terhadap anak didiknya. Seorang guru tidak hanya bertugas untuk mentrasfer ilmu pengetahuan semata, tetapi jauh lebih berat yaitu untuk mengarahkan dan membentuk perilaku atau kepribadian anak didik, terlebih guru PAI.

Bagi guru PAI, yang juga merupakan mubalig, pembelajaran adalah salah satu saluran penyampaian dakwah islamiah sehingga metode ceramah merupakan salah satu metode andalan dalam rangka menggugah rasa peserta didik untuk menerima ajaran-ajaran agama Islam. Penggunaan metode ceramah ini biasanya tanpa dibantu dengan media pembelajaran dengan alasan bahwa dengan retorika dakwah bil lisan peserta didik dapat menerima pesan-pesan pembelajaran dengan baik. Ini merupakan salah satu faktor penyebab kurangnya perhatian guru PAI dalam menggunakan dan mengembangkan media pembelajaran.

Di samping hal tersebut di atas, sebagian guru PAI masih terpaku pada pola pikir bahwa ada atau tidak ada media pembelajaran maka pembelajaran akan tetap berjalan. Pola pikir seperti ini menimbulkan sikap apatis sehingga guru PAI tidak memperhatikan pentingnya penggunaan media pembelajaran. Akhirnya yang terjadi adalah pembelajaran menjadi kegiatan yang monoton dan kurang variasi sehingga membuat peserta didik jenuh yang pada akhirnya menjadi kurang kreatif.

Pada perkembangan dewasa ini, guru PAI diharapkan menjadi sumber inspirasi bukan hanya dari segi keteladanan budi pekerti tetapi juga dari segi aplikasi teknologi dalam pembelajaran PAI. Guru PAI harus terus mengikuti perkembangan teknologi dan menyesuaikan proses pembelajarannya dengan kemajuan tersebut. Misalnya ketika mengajarkan aspek Alquran guru PAI harus memperkenalkan berbagai aplikasi Alquran digital yang dapat diperoleh secara online dan bahkan bisa menjadi media dalam proses pembelajaran PAI. Perkembangan yang menggembirakan adalah organisasi profesi guru PAI sudah memfasilitasi guru PAI dalam kegiatan pelatihan pengembangan media berbasis android. Namun, tidak semua guru PAI meluangkan waktu untuk mengikuti kegiatan tersebut dengan berbagai alasan.

Sebagian guru PAI juga menjadi terkadang menjadi apatis melihat perkembangan sikap peserta didik dari hari ke hari yang terkesan "kurang taat" pada instruksi guru. Misalnya ketika diberi tugas tertentu, hanya sebagian kecil saja yang peserta didik yang mau melakukannya atau mengerjakannya dan itu pun dilakukan seadanya saja. Hal seperti ini membuat guru PAI sedikit frustrasi tanpa dibarengi dengan upaya meningkatkan kualitas proses pembelajaran, salah satunya dengan penggunaan dan pengembangan media pembelajaran.

Pengawas PAI, yang salah satu tugasnya adalah pembinaan guru PAI, harus mengambil peran dalam mencari solusi dalam masalah ini karena proses pembelajaran PAI di sekolah menjadi kegiatan

\footnotetext{
${ }^{1}$ Sultan Hasanuddin, "Pembinaan Mahasiswa Prodi Pendidikan Agama Islam Yang Aktif Pada Organisasi Mahasiswa Iain Bone,” Ekspose: Jurnal Penelitian Hukum Dan Pendidikan 17, no. 1 (2019): 539-48.

${ }^{2}$ Marzuki, Pendidikan Karakter Islam (Jakarta: Amzah, 2015).
} 
pokok dalam membentuk manusia yang beriman dan bertakwa kepada Tuhan Yang Maha Esa sesuai amanah undang-undang. ${ }^{3}$ Pengawas dalam menjalankan tugas dan fungsinya diharapkan berperan penting dalam memotivasi guru PAI untuk senantiasa berinovasi dan berkreasi dalam pelaksanaan pembelajaran di kelas. Di samping itu pengawas juga dapat melakukan choacing terkait tugas-tugas guru PAI untuk meningkatkan kompetensinya.

Disadari atau tidak, bahwa tugas kepengawasan terkadang dianggap sebelah mata oleh guru PAI. Masih ada guru PAI yang sedikit "alergi" jika harus berhadapan dengan pengawas karena menganggap bahwa keberadaan pengawas hanya sebagai pemantau saja tanpa harus membina atau membimbing. Ada juga yang beranggapan bahwa ada atau tidak ada pengawas mereka tetap dapat melaksanakan tugas dan fungsinya sebagai guru. Hal ini menjadi tantangan tersendiri bagi pengawas PAI karena tugas kepengawasan PAI adalah tugas yang berat karena meliputi tugas pemantauan, pembinaan, penilaian, dan pembimbingan guru PAI. ${ }^{4}$

Jadi, pengawas PAI akan ikut bertanggung jawab jika standar kompetensi lulusan yang terkait dengan keimanan, ketakwaan, dan budi pekerti peserta didik tergolong dalam kategori rendah. Maka dalam hal ini, pengawas harus memiliki program pembinaan dan pembimbingan terkait dengan penggunaan dan pengembangan media pembelajaran demi untuk membantu guru PAI dalam melaksanakan proses pembelajaran yang lebih baik lagi.

\section{PEMBAHASAN}

\section{Penggunaan dan Pengembangan Media Pembelajaran PAI}

Pendidikan Agama Islam merupakan upaya sadar dan terencana dalam menyiapkan peserta didik untuk mengenal, memahami, menghayati, hingga mengimani, bertakwa, dan berakhlak mulia dalam mengamalkan ajaran agama Islam dari sumber utamanya yaitu kitab suci Al-Quran dan Hadits melalui kegiatan bimbingan pengajaran, latihan, serta penggunaan pengalaman.

Pembelajaran PAI adalah pembelajaran yang memiliki kekhasan dan karakteristik tersendiri dibanding pembelajaran lainnya. Orientasi pembelajaran PAI di sekolah secara umum adalah mewujudkan peserta didik yang beriman dan bertakwa kepada Tuhan Yang Maha Esa ditandai dengan kebaikan budi pekerti. Maka seluruh materi pokok harus diarahkan pada pembentukan sikap. Tujuan PAI tidak lepas dari dari tujuan pendidikan Islam yang menurut Abu Ahmadi tujuannya adalah membentuk peserta didik untuk menjadi hamba Allah, menjadi khalifah di bumi, dan memperoleh kesejahteraan dunia dan akhirat. ${ }^{5}$

Pembelajaran PAI memiliki karakter yang membedakannya dengan pelajaran lainnya, yaitu: Merujuk pada aturan-aturan yang sudah pasti, Selalu mempertimbangkan dua sisi kehidupan duniawi dan ukhrawi dalam setiap langkah dan geraknya, Bermisikan pembentukan akhlakkula karimah, Diyakini sebagai dakwah atau misi suci. Pembelajaran PAI juga memiliki sifat pengajaran dalam kurikulum yang berbeda dengan mata pelajaran lainnya sebagaimana dikemukakan oleh Abdullah Nashih Ulwan sebagai berikut: Kurikulum PAI mempunyai dua sisi muatan' yaitu muatan wahyu dan pengetahuan, Kurikulum PAI bersifat memihak, tidak netral, Kurikulum PAI mengarahkan pada pembentukan akhlak mulia, Kurikulum PAI bersifat fungsionl terpakai sepanjang masa, dan Materi kurikulum PAI sudah ada pada setiap peserta didik sejak dari rumah. ${ }^{6}$

Materi pokok pada PAI meliputi 5 aspek yaitu Alquran, Akidah, Akhlak, Fiqih, dan Sejarah Kebudayaan Islam. Setiap aspek memiliki karakter tersendiri pula sehingga akan berpengaruh pada penetapan metode dan pemilihan media pembelajaran. Dalam menyajikan materi pokok PAI yang kompleks itulah guru PAI dituntut untuk kreatif dan inovatif. Salah satunya adalah keterampilan menyiapkan dan menggunakan media pembelajaran serta mengembangkannya.

Proses pembelajaran pada hakikatnya adalah proses komunikasi, yaitu proses penyampaian pesan dari sumber pesan melalui saluran/media tertentu kepada penerima pesan. pesan yang akan dikomunikasi adalah materi pokok yang termuat dalam kurikulum, sumber pesannya bisa guru, peserta

\footnotetext{
3 Presiden Republik Indonesia, "Undang-Undang Republik Indonesia Nomor 20 Tahun 2003 Tentang Sistem Pendidikan Nasional,” Pub. L. No. 20, 79 (2003).

${ }^{4}$ PMARI, "Pengawas Madrasah Dan Pengawas Pendidikan Agama Islam Pada Sekolah" (2012)

${ }^{5}$ Abu Achmadi, Islam Sebagai Paradigma Ilmu Pendidikan (Yogyakarta: Aditya Media, 1992).

${ }^{6}$ Abd Allah Nasih'Ulwan et al., Pedoman Pendidikan Anak Dalam Islam (Victorie Agencie, 1996).
} 
didik, orang lain ataupun penulis buku dan produser media; salurannya media pendidikan dan penerima pesannya adalah peserta didik atau juga guru. ${ }^{7}$

Guru dalam mengelola pembelajaran disamping harus mampu menggunakan media yang tersedia, guru juga dituntut untuk dapat mengembangkan keterampilan membuat media pembelajaran yang akan digunakannya apabila media tersebut belum tersedia. Untuk itu guru harus memiliki pengetahuan dan pemahaman yang cukup tentang media pembelajaran sebagaimana dikatakan oleh Hamalik, sebagaimana dikutip oleh Azhar Arsyad, meliputi: media sebagai alat komunikasi guna lebih mengefektifkan proses pembelajaran; fungsi media dalam rangka mencapai tujuan pendidikan; selukbeluk proses pembelajaran; hubungan antara metode mengajar dan media pendidikan; nilai atau manfaat mediap pendidikan dalam pembelajaran; pemilihan dan penggunaan media pendidikan; berbagai jenis alat dan teknik media pendidikan; media pendidikan dalam setiap mata pelajaran; dan usaha inovasi dalam media pendidikan. ${ }^{8}$

Menurut Azhar Arsyad ada beberapa manfaat praktis dari penggunaan media pembelajaran sebagai berikut: Media Pembelajaran dapat memperjelas penyajian pesan dan informasi sehingga dapat memperlancar dan meningkatkan proses dan hasil belajar; Media pembelajaran dapat meningkatkan dan mengarahkan perhatian peserta didik sehingga dapat menimbulkan moteivasi belajar, interaksi yang lebih langsung antara peserta didik dan lingkungannya, dan kemungkinan peserta didik untuk belajar sendiri-sendiri sesuai dengan kemampuan dan minatnya; Media pembelajaran dapat mengatasi keterbatasan indera, ruang, dan waktu; Media pembelajaran dapat memberikan kesamaan pengalaman kepada peserta didik tentang peristiwa-peristiwa di lingkungan mereka, serta memungkinkan terjadinya interaksi langsung dengan guru, masyarakat, dan lingkungannya misalnya melalui karyawisata, kunjungan-kunjungan ke museum atau kebun-kebun binatang. ${ }^{9}$

Seiring lajunya perkembangan teknologi informasi dan komunikasi makin banyak media yang bisa digunakan sekaligus dikembangkan. Tersedia banyak media yang bisa dijadikan media pembelajaran baik yang berupa gambar, audio, video, atau pun perpaduan dari ketiganya. Ada media yang sudah jadi yang bisa langsung digunakan oleh guru PAI, misalnya tersedianya video tutorial tata cara berwudhu, shalat, haji, perawatan jenazah, dan lain-lain. Ada pula yang harus dikembangkan sendiri oleh guru PAI berupa gambar, video, dan audio yang ada kaitannya dengan materi pokok tetapi harus diramu sedemikian rupa menjadi media pembelajaran yang menarik dan efektif.

Pengembangan media pembelajaran PAI bisa dilakukan dengan memadukan antara satu media dengan media lainnya. Misalnya media yang berupa lafaz-lafaz ayat Alquran tanpa suara bisa dipadukan dengan media Alquran yang berbentuk audio saja. Bisa pula dikembangkan dalam bentuk materi presentasi power point yang mengandung lafaz dan suara sekaligus ataukah media yang berbasis adobe flash. Video-video yang tersedia di youtube juga bisa menjadi alternatif lain yang bisa dikembangkan sedemikian rupa. Misalnya visualisasi gambaran syurga dan neraka bisa dikembangkan dengan mencari video berisi gambaran taman-taman indah untuk visualisasi syurga dan video berisi gambara kebakaran dahsyat untuk visualisasi neraka. Ataukah mencari video yang sudah jadi dalam bentuk animasi yang diformat khusus untuk memvisualisasikan syurga dan neraka. Dan banyak lagi cara untuk mengembangkan media pembelajaran PAI tergantung dari kreatifitas dan inovasi guru PAI.

Guru dapat memanfaatkan media dan sumber belajar dengan mempertimbangkan efektifitasnya sebagai berikut: Sejauhmana media dan sumber belajar bermanfaat dalam mencapai sasaran belajar; Sejauhmana manfaat isi pengetahuan yang terdapat dalam surat kabar, majalah, radio, televisi, museum dan kantor-kantor untuk pokok bahasan tertentu; dan Apakah isi pengetahuan di museum, tempat wisata bersejarah, kebun bibit, kebun binatang, dan perpustakaan umum bermanfaat bagi pokok bahasan tertentu. Jika ya, maka guru harus memanfaatkan dan membuat program karya wisata. ${ }^{10}$

Guru PAI bahkan bisa membuat sendiri media pembelajaran PAI. Apalagi didukung dengan berbagai aplikasi, baik yang berbasis komputer maupun android. Kecanggihan teknologi memudahkan guru PAI untuk membuat sendiri media pembelajaran. Ada beberapa hal yang perlu diperhatikan dalam

${ }^{7}$ S Sadiman Arif, Media Pendidikan: Pengertian Pengembangan Dan Pemanfaatannya (Jakarta: Raja Grafindo Persada, 2003).

${ }^{8}$ Azhar Arsyad, Media Pembelajaran Edisi Revisi (Jakarta: Rajawali Pers, 2013).

${ }^{9}$ Arsyad.

${ }^{10}$ Mudjiono Dimyati, Belajar Dan Pembelajaran (Jakarta: Rineka Cipta, 2006). 
membuat media pembelajaran, yaitu sebagai berikut: Tentukan jenis multimedia pembelajaran; Tentukan tema materi ajar; Susun alur cerita (storyboard); Gunakan teknik ATM (Amati, Tiru, Modifikasi); Tetapkan target; Ingat tiga resep dari succes story, yaitu berani mencoba, belajar mandiri, dan tekun dan tidak menyerah; dan Mulai buat sekarang. ${ }^{11}$

\section{Peran Pengawas}

Secara umum pengawasan dapat diartikan sebagai proses kegiatan pemantauan untuk meyakinkan bahwa semua kegiatan organisasi terlaksana seperti yang direncanakan dan sekaligus juga merupakan kegiatan untuk mengoreksi dan memperbaiki bila ditemukan adanya penyimpangan yang akan mengganggu pencapaian tujuan. ${ }^{12}$ Selanjutnya Burhanuddin mengartikan pengawasan atau supervisi pendidikan tidak lain dari usaha memberikan layanan kepada stakeholder pendidikan, terutama kepada guru-guru, baik secara individu maupun secara kelompok dalam usaha memperbaiki kualitas proses dan hasil pembelajaran. ${ }^{13}$

Selanjutnya Syaiful dalam bukunya supervisi pembelajaran mengartikan supervisi mempunyai arti khusus yaitu "membantu dan turut serta dalam usaha-usaha perbaikan dan meningkatkan mutu baik personel maupun lembaga. Dalam dunia pendidikan memandang guru sebagai bagian penting dari manajemen yang diharapkan melaksanakan tugas sesuai fungsi-fungsi manajemen dengan baik dan terukur". ${ }^{14}$ Jadi, pengawas PAI sebagai bagian penting dalam manajemen sekolah harus membantu guruguru, yang juga bagian dari manajemen, dalam melaksanakan tugas sesuai fungsi-fungsi manajemen dengan baik dan terukur.

Khusus dalam efektivitas penggunaan dan pengembangan media pembelajaran, pengawas bisa berperan aktif dalam beberapa bentuk atau cara, yaitu: Mengoptimalkan supervisi akademik, Pengawas sebagai motivator, Pengawas sebagai peneliti, Pengawas sebagai penilai, Pengawas sebagai konsultan, Pengawas sebagai sumber inspirasi, dan Pengawas sebagai pelopor perubahan.

\section{Mengoptimalkan Supervisi Akademik}

Sasaran supervisi akademik antara lain adalah untuk membantu guru dalam hal: merencanakan kegiatan pembelajaran dan atau bimbingan, melaksanakan kegiatan pembelajaran/bimbingan, menilai proses dan hasil pembelajaran/bimbingan, memanfaatkan hasil penilaian untuk peningkatan layanan pembelajaran/bimbingan, memberikan umpan balik secara tepat dan teratur dan terus menerus pada peserta didik, melayani peserta didik yang mengalami kesulitan belajar, memberikan bimbingan belajar pada peserta didik, menciptakan lingkungan belajar yang menyenangkan, mengembangkan dan memanfaatkan alat bantu dan media pembelajaran dan atau bimbingan, memanfaatkan sumber-sumber belajar, mengembangkan interaksi pembelajaran/bimbingan (metode, strategi, teknik, model, pendekatan, media, dan sebagainya) yang tepat dan berdaya guna, melakukan penelitian praktis bagi perbaikan pembelajaran/bimbingan, dan mengembangkan inovasi pembelajaran/bimbingan.

Menurut Oliva sebagaimana dikutip oleh Syaiful (2010:103 ) mengatakan bahwa ada beberapa hal yang dilakukan pengawas sekolah sebagai supervisor untuk membantu guru agar tetap bekerja secara professional yaitu: Membantu guru membuat perencanaan pembelajaran, Membantu guru untuk menyajikan pembelajaran, Membantu guru untuk mengevalusikan pembelajaran, Membantu guru untuk mengelola kelas, Membantu guru dalam mengembangkan kurkulum, Membantu guru dalam mengevaluasi kurikulum, Membantu guru dalam program pelatihan, Membantu guru dalam bekerja sama, dan Membantu guru dalam mengevaluasi diri.

Jadi, dalam supervisi akademik pengawas PAI membantu guru dalam merencanakan pembelajaran dengan mempersiapkan media pembelajaran yang sesuai berdasarkan hasil refleksi dari kegiatan supervisi sebelumnya. Terkadang pula guru PAI sudah mencantumkan jenis media dalam perencanaannya tetapi dalam pelaksanaannya tidak terealisasi. Di situ pula peran pengawas dalam

\footnotetext{
${ }^{11}$ Dimyati.

${ }^{12}$ Nana Sudjana, "Standar Mutu Pengawas" (2006).

${ }^{13}$ Analisis Administrasi Burhanudin, Manajemen, Dan Kepemimpinan Pendidikan (Jakarta: Bumi Aksara, 1994).

${ }^{14}$ Ahmad Sabandi, "Supervisi Pendidikan Untuk Pengembangan Profesionalitas Guru Berkelanjutan," Pedagogi: Jurnal Ilmu Pendidikan 13, no. 2 (2013): 1-9.
} 
observasi kelas untuk melihat komoitmen guru dalam melaksanakan pembelajaran apakah sesuai perencanaan atau tidak, dan atau melihat keterampilan guru dalam menggunakan media apakah sudah baik atau masih perlu ditingkatkan. Selanjutnya pengawas akan membantu guru dalam mengevaluasi penggunaan media dalam pelaksanaan pembelajaran untuk lebih meningkatkan lagi mutu proses pembelajaran selanjutnya.

\section{Pengawas Sebagai Motivator}

Seorang pengawas hendaknya membangkitkan dan memelihara kegairahan kerja guru untuk mencapai prestasi kerja yang semakin baik, mendorong guru-guru untuk mempraktikkan gagasangagasan baru yang dianggap baik bagi penyempurnaan proses pembelajaran, berkolaborasi dengan guru untuk mewujudkan perubahan yang dikehendaki, dan menyediakan stimulus yang memungkinkan usaha-usaha pembaru yang dapat dilaksanakan dengan sebaik-baiknya. ${ }^{15}$

Guru dalam statusnya sebagai manusia juga memiliki gairah atau semangat kerja yang naik turun sehingga peran pengawas sangat diharapkan untuk menjadi motivator. Pengawas harus bisa mengetahui profil dari seluruh guru binaannya, mulai dari latar belakang budaya, pendidikan, kehidupan keluarga, dan lain sebagainya. Hal itu semua menjadi bahan pertimbangan bagi seorang pengawas untuk memberikan motivasi kepada mereka. Kaitannya dengan penggunaan dan pengembangan media pembelajaran, pengawas harus memberi dorongan kepada guru PAI untuk senantiasa mengembangkan diri baik melalui pendidikan dan latihan maupun belajar secara otodidak dalam mengembangkan media pembelajaran yang relevan untuk mata pelajaran PAI.

\section{Pengawas Sebagai Peneliti}

Salah satu kompetensi yang harus dimiliki oleh pengawas adalah penelitian pengembangan. Pengawas harus menguasai berbagai pendekatan, jenis dan metode penelitian dlm pendidikan; Menentukan masalah kepengawasan yang penting utk diteliti; Menyusun proposal penelitian pendidikan; Melaksanakan penelitian pendidikan; Mengolah dan menganalisis data hasil penelitian; Menulis karya ilmiah; Menyusun pedoman untuk tugas kepengawasan; dan Memberikan bimbingan guru tentang penelitian. ${ }^{16}$

Seorang pengawas dituntut untuk mengenal dan memahami masalah-masalah pembelajaran. Karena itu ia perlu mengidentifikasi masalah-masalah pembelajaran dan mempelajari faktor-faktor atau sebab-sebab yang mempengaruhi. ${ }^{17}$ Hasil dari penelitiannya itulah nanti yang dapat dijadikan acuan dalam memperbaiki pembinaannya terhadap guru bunaan.

Terkait dengan penggunaan dan pengembangan media pembelajaran, pengawas dapat melakukan penelitian untuk mengetahui faktor-faktor yang mempengaruhi minat guru dalam menggunakan media pembelajaran, atau bisa pula menguji coba suatu media pembelajaran untuk melihat efektivitas dan efisiensi penggunaannya, atau pengaruh media dalam meningkatkan minat belajar peserta didik, dan lain sebagainya. Pengawas harus lebih kreatif dalam melaksanakan tugasnya demi terwujudnya guru PAI yang lebih kompeten, kreatif, dan inovatif.

\section{Pengawas Sebagai Penilai}

Kompetensi lain yang harus dimiliki oleh pengawas adalah kompetensi evaluasi pendidikan. Pengawas harus bisa menyusun kriteria dan indikator keberhasilan pengawasan, membimbing guru dalam menentukan aspek-aspek penting yang dinilai dlm pembelajaran, menilai kinerja guru dlm melaksanakan tugas pokoknya, memantau pelaksanaan pembelajaran, membina guru dalam memanfaatkan hasil penilaian, dan mengolah dan menganalisis data hasil penilaian kinerja guru. ${ }^{18}$ Pengawas harus sanggup bersama dengan guru untuk menemukan kemajuan-kemajuan apa saja yang

${ }^{15}$ Asf Jasmani and Syaiful Mustofa, "Supervisi Pendidikan Terobosan Baru Dalam Peningkatan Kinerja Pengawas Sekolah Dan Guru” (Yogyakarta: Ar Ruzz Media, 2013).

${ }^{16}$ Permendiknas, "Standar Pengawas Sekolah" (2007).

${ }^{17}$ Jasmani and Mustofa, "Supervisi Pendidikan Terobosan Baru Dalam Peningkatan Kinerja Pengawas Sekolah Dan Guru."

${ }^{18}$ Permendiknas, Standar Pengawas Sekolah. 
telah dicapai, hambatan-hambatan atau kekurangan/kelemahan apa saja yang masih dirasakan, dan sebab-sebab masih adanya hambtan atau kekurangan/kelemahan tersebut. ${ }^{19}$

Guru yang dinilai dalam pelaksanaan tugasnya akan mengetahui kekuatan dan kelemahannya. Sehingga kekuatan yang dimilikinya akan semakin ditingkatkan dan kelemahannya akan diperbaiki secara berkelanjutan. Guru yang selalu diberi penilaian oleh pengawas juga akan senantiasa merasa diawasi dan diperhatikan setiap saat sehingga walaupun pengawas tidak hadir setiap saat tetapi dampaknya akan sangat besar jika penilaiannya dilakukan sesuai prosedur.

Oleh karenanya, pengawas sebagai penilai harus mampu menilai dengan prinsip jujur apa adanya dan transparan demi terwujudnya guru yang lebih kompeten. Termasuk dalam menggunakan dan mengembangan media pembelajaran, pengawas harus menilai pengetahuan, sikap, dan keterampilan guru dalam penggunaan dan pengembangan media pembelajaran.

\section{Pengawas Sebagai Konsultan}

Seorang pengawas hendaknya dapat membantu guru untuk melakukan cara-cara yang lebih baik dalam mengelola pembelajaran. Oleh sebab itu, pengawas hendaknya selalu mengikuti perkembangan masalah-masalah dan gagasan-gagasan pendidikan dan pembelajaran mutakhir. Ia dituntut untuk banyak membaca dan menghadiri pertemuan-pertemuan profesional, yang mana ia memiliki kesempatan untuk tukar informasi tentang masalah-masalah pendidikan dan pembelajaran yang relevan, yaitu gagasangagasan baru mengenai teori dan praktik. ${ }^{20}$

Dengan senantiasa mengembangkan diri pengawas akan bisa menjadi konsultan bagi guru binaannya. Demikian halnya dalam penggunaan dan pengembangan media pembelajaran, pengawas juga harus terus mengikuti perkembangan ilmu pengetahuan dan teknologi agar masalah-masalah yang terkait dengan media pembelajaran mutakhir bisa dicarikan solusinya bersama guru PAI. Pengawas harus bisa menjemput bola, yang mana guru-guru yang terkadang bersikap apatis harus bisa digerakkan oleh pengawas melalui konsultasi terkait masalah pembelajaran yang hadapinya.

Sebagai konsultan pengawas akan melakukan hal sebagai berikut: Bersama guru-guru mengikhtiarkan cara-cara untuk mengatasi kekurangan atau hambatan yang dirasakan; Bersama guruguru mencari jalan mempertahankan yang sudah baik, bahkan berusaha terus meningkatkannya agar lebih baik; Menyedeiakan waktu dan tenaganya untuk mengadakan perbaikan-perbaikan; Mengikhtiarkan sumber-sumber, baik material maupun personil, dan menunjukkan jalan pengadaan dan penggunaannya; dan Mengusahakan untuk menyebarluaskn keberhasilan-keberhasilan yang telah dicapai guru lainnya beserta bimbingannya. ${ }^{21}$

\section{Pengawas Sebagai Sumber Inspirasi}

Pengawas PAI harus menunjukkan kepada guru binaannya bahwa walaupun sudah menempati posisi tertinggi dalam jabatan fungsional pengawas tetap selalu memacu diri untuk belajar dan terus mengembangkan diri baik melalui pendidikan dan latihan maupun dengan belajar mandiri demi menjadi seorang pengawas yang profesional yang bisa menjadi teladan bagi guru-guru PAI.

Pengawas PAI yang disiplin dalam melaksanakan tugas, ramah dalam membina guru-guru, cerdas dalam menjawab permasalahan-permasalahan pendidikan dan pembelajaran, punya jiwa kepemimpinan yang baik, tekun dalam menjalankan ibadah, niscaya akan menjadi pengawas yang inspiratif sehingga guru-guru lambat laun akan mengikuti "irama"-nya yang pada muaranya akan mewujudkan guru yang profesional yang melaksanakan tugas pembelajaran yang kreatif dan inovatif.

\section{Pengawas Sebagai Pelopor Perubahan}

Pengawas yang efektif adalah seorang pelaku dan bahkan pelopor perubahan pendidikan, dan efektivitasnya bergantung pada kepekaan terhadap masalah-masalah yang dihadapi maupun pada wawasannya mengenai strategi perubahan. Kenyataannya, inovasi-inovasi pendidikan dan informasi

\footnotetext{
${ }^{19}$ Pupuh Fathurrohman and Aa Suryana, Supervisi Pendidikan Dalam Pengembangan Proses Pendidikan (Bandung: PT. Refika Aditama, 2011).

${ }^{20}$ Jasmani and Mustofa, "Supervisi Pendidikan Terobosan Baru Dalam Peningkatan Kinerja Pengawas Sekolah Dan Guru."

21 Jasmani and Mustofa.
} 
baru telah berada di hadapan pengawas, dan sebelum ia dapat menilainya, apalagi menerapkannya, ia harus lebih dahulu memahami pentingnya pembaharuan itu. ${ }^{22}$

Dalam situasi dan konteks perubahan masyarakat yang cepat, kompleks, dan sulit untuk diprediksi dewasa ini, basis-basis empiris dalam melakukan suatu kegiatan menjadi tuntutan yang perlu diantisipasi oleh pengawas agar perannya bisa lebih membumi dan relevan dengan dinamika sosial budaya masyarakat. Kebijakan formal tentang posisi pengawas perlu dikaji ulang serta dapat diperkaya dengan tugas yang terkait dengan interaksi organisasi sekolah dengan masyarakat, termasuk yang terkait dengan local genius, sehingga dapat memberikan layanan bantuan guna memperkuat kapabilitas organisasi berperan efektif dalam masyarakat yang terus berubah. ${ }^{23}$

Pengawas harus mampu menjadi contoh dalam inovasi pembelajaran khususnya dalam pengembangan media pembelajaran. Media pembelajaran mengalami transformasi seiring dengan perkembangan ilmu pengetahuan dan teknologi. Fungsi media pun akan semakin meningkat karena kompleksitas dan kecanggihannya mengikuti laju kecanggihan teknologi. Pola pikir lama sebagai guru harus mampu dirubah oleh pengawas agar terjadi perubahan ke arah yang lebih baik.

\section{SIMPULAN DAN SARAN}

\section{Simpulan}

Dari uraian tersebut di atas dapat disimpulkan bahwa: Materi Pendidikan Agama Islam (PAI) sebagai materi pembelajaran yang memiliki kekhasan dan karakteristik tersendiri juga memerlukan pengembangan media sesuai dengan karakteristik PAI; Guru PAI sebagai pelaku langsung dalam pembelajaran PAI harus berupaya mengembangkan media pembelajaran yang relevan dengan materi PAI dan seirama dengan perubahan teknologi yang semakin maju untuk menyajikan pembelajaran yang efektif dan efisien; dan engawas PAI memiliki peran penting dalam efektivitas penggunaan dan pengembangan media pembelajaran yaitu dengan mengoptimalkan supervisi akademik, menjadi motivator, peneliti, penilai, konsultan, sumber inspirasi, dan pelopor perubahan.

Saran

Sebaiknya guru PAI senantiasa mengembangkan diri untuk dapat mengembangkan media pembelajaran yang efektif dan efisien. Selain itu, sebaiknya pengawas PAI juga menjadi motor penggerak bagi guru-guru PAI dalam mengembangkan media pembelajaran. Pemerintah juga harusnya memfasilitasi guru dalam berkreasi dan berinovasi dalam bentuk pelatihan atau kegiatan lain yang tujuannya untuk menumbuhkan kreativitas dan inovasi dalam meningkatkan mutu pembelajaran.

\section{DAFTAR PUSTAKA}

Achmadi, Abu. Islam Sebagai Paradigma Ilmu Pendidikan. Yogyakarta: Aditya Media, 1992.

Arif, S Sadiman. Media Pendidikan: Pengertian Pengembangan Dan Pemanfaatannya. Jakarta: Raja Grafindo Persada, 2003.

Arsyad, Azhar. Media Pembelajaran Edisi Revisi. Jakarta: Rajawali Pers, 2013.

Burhanudin, Analisis Administrasi. Manajemen, Dan Kepemimpinan Pendidikan. Jakarta: Bumi Aksara, 1994.

Dimyati, Mudjiono. Belajar Dan Pembelajaran. Jakarta: Rineka Cipta, 2006.

Fathurrohman, Pupuh, and Aa Suryana. Supervisi Pendidikan Dalam Pengembangan Proses Pendidikan. Bandung: PT. Refika Aditama, 2011.

Hasanuddin, Sultan. "Pembinaan Mahasiswa Prodi Pendidikan Agama Islam Yang Aktif Pada Organisasi Mahasiswa Iain Bone.” Ekspose: Jurnal Penelitian Hukum Dan Pendidikan 17, no. 1 (2019): 539-48.

Indonesia, Presiden Republik. Undang-undang Republik Indonesia nomor 20 tahun 2003 tentang sistem pendidikan nasional, Pub. L. No. 20, 79 (2003).

Jasmani, Asf, and Syaiful Mustofa. "Supervisi Pendidikan Terobosan Baru Dalam Peningkatan Kinerja Pengawas Sekolah Dan Guru." Yogyakarta: Ar Ruzz Media, 2013.

Marzuki. Pendidikan Karakter Islam. Jakarta: Amzah, 2015.

\footnotetext{
22 Jasmani and Mustofa.

${ }^{23}$ Uhar Suharsaputra, Supervisi Pendidikan: Pendekatan Sistem Berbasis Kinerja (Bandung: PT. Refika Aditama, 2018).
} 
Nasih'Ulwan, Abd Allah, Saifullah Kamalie, Hery Noer Ali, and Anwar Rasyidi. Pedoman Pendidikan Anak Dalam Islam. Victorie Agencie, 1996.

Permendiknas. Standar Pengawas Sekolah (2007).

PMARI. Pengawas Madrasah dan Pengawas Pendidikan Agama Islam pada Sekolah (2012).

Sabandi, Ahmad. "Supervisi Pendidikan Untuk Pengembangan Profesionalitas Guru Berkelanjutan." Pedagogi: Jurnal Ilmu Pendidikan 13, no. 2 (2013): 1-9.

Sudjana, Nana. Standar Mutu Pengawas (2006).

Suharsaputra, Uhar. Supervisi Pendidikan: Pendekatan Sistem Berbasis Kinerja. Bandung: PT. Refika Aditama, 2018. 